\title{
Great expectations? Enterprises' expectations about graduate education in the field of management: Evidence from Slovenia ${ }^{*}$
}

\author{
Bogdan Lipičnik, Katarina Katja Mihelič**
}

As a response to the emerging trend of greater enrolment in graduate programmes in Slovenia, this paper assesses the role of higher education (i.e. specifically in the management field) in Slovenian enterprises. The research includes representatives from 80 enterprises and 160 graduate students. It is believed that knowledge and other individual's capabilities obtained in the process of formal education are utilized in companies. However, the opposing belief among students that enterprises do not seek candidates with graduate degrees emphasizes the importance of a deeper investigation of the subject. Research data show that graduate education can be seen not only as an advantage but also as a disadvantage.

Als eine Antwort auf den immer wichtiger werdenden Trend von steigenden Anmeldungen für Graduiertenprogramme in Slowenien, geht der Aufsatz auf die Rolle der höheren Bildung (insbesondere im Managementbereich) in slowenischen Unternehmen ein. Die Forschung schließt Repräsentanten von 80 Unternehmen und 160 Schulabgänger mit ein. Es wird angenommen, dass Wissen und andere individuelle Fähigkeiten, die in der formalen Bildung angeeignet werden, in Unternehmen genutzt werden. Aber die Gegenseite unter den Studenten glaubt, dass Großkonzerne nicht nach Graduierten suchen, um so wichtiger sei es, eine vertiefte Ausbildung zu haben. Die Forschungsdaten haben gezeigt, dass die abgeschlossene Ausbildung nicht nur als Vorteil sondern auch als Nachteil gesehen wird.

Key words: management; Knowledge; graduate studies; Slovenia; research

\footnotetext{
* Manuscript received: 23.02.06, accepted: 02.12.06 (1 revision)

** Bogdan Lipičnik, PhD, University of Ljubljana. Main research areas: Organizational Behavior and theory, human resource management, motivation and leadership and group behaviour. Corresponding address: bogdan.lipicnik@ef.uni-lj.si

Katarina Katja Mihelič, MSc., University of Ljubljana. Main research areas: Mangement and leadership, Human resources management, knowledge management and education. Corresponding address: katja.mihelic@ef.uni-lj.si
} 


\section{Introduction}

The emerging knowledge-driven society is changing the requirements and demands regarding formal education and capabilities on the labour market. Knowledge is becoming an increasingly important factor in the accumulation of value. Its presence is crucial in the struggle for economic growth, productivity and competition at micro as well as macro level. Adam Smith emphasized that the improvement of workers' skills was a fundamental source of economic progress whereas John Stuart Mill regarded education as an important investment in society (Eliasson 2000).

The knowledge economy, which introduces knowledge as the dominant factor of production, has created a leading social group known as "knowledge-workers", who are above all skilled, independent, hard working and ambitious. Such people occupy the managerial positions in enterprises at all levels. They trade their knowledge, expertise and skill. In other words, they are people with sought-after capabilities (Brown/Hesketh 2004; Drucker 1993).

Managers possess knowledge, which is a part of capabilities, and if they enrich it with creativity, this ensures a competitive advantage that is sustained so as to fulfil a company's objectives. The speed of development is accelerating and, to achieve the desired efficiency, one will have to adapt to the increasing number of changes even faster by applying old and new competences. Enterprises demand workers with even more skills and knowledge, or they will not be able to keep pace with ever faster changes (Delors et al. 1996). If the success of a national economy is increasingly dependent on knowledge, it is of crucial importance to explore the role of education and knowledge in greater detail. This paper focuses on knowledge acquired in the formal process of education, and the subject addressed is narrowed down to graduate education at the master's level in the field of management. As a response to greater enrolment in graduate programmes, we wish to assess the expectations regarding graduate education in Slovenian enterprises. Therefore, the intention is to explore how students in graduate programmes in the field of management and Slovenian enterprises perceive graduate education and whether there are any differences in their perceptions. It is important to explore what expectations enterprises and their managers have about managerial capabilities obtained in graduate programmes and whether they see them as useful in solving day-to-day problems.

The paper is divided into five parts. First, we present the theoretical background of management education including concepts of learning, competencies and the trend of growing enrolment in graduate programmes. An examination of trends in management education and managerial capabilities follows. Next, research samples and methodology are explained. In the fourth section the empirical findings are presented and interpreted. The conclusion summarizes the main findings and provides some directions for future research. 


\section{Background}

\subsection{Definition of the concepts}

According to European qualifications framework, "learning is a cumulative process where individuals gradually assimilate increasingly complex and abstract entities and/or acquire skills and wider competences" (Commission of the European communities. 2005: 10). Learning is considered necessary in order to be employable (Garsten/Jacobson 2004). Learning is therefore a continuous changing of activities that have a relatively permanent effect (Pečjak 1977). The goal of learning is not solely to acquire the knowledge of a particular topic - it is also training one's intellectual abilities.

Knowledge, the consequence of learning, represents a part of human ability gained in various ways that enables managers to solve problems with solutions that are already familiar. However, problems with solutions that are unfamiliar are solved by combining knowledge with abilities (Lipičnik 1998).

The literature is still not united as to what terminology to use when discussing the individual qualities needed to function in complex business environment. Particularly in managerial positions, candidates are required to have different competences. McClelland argues that a competence is a performance capability that distinguishes effective from ineffective managers in a particular organization (Hogan/Warrenfeltz 2003, Hornby/Thomas 2005). Mirable defines competence as a knowledge, skill, ability or characteristic associated with high performance on a job. According to European Qualifications framework, the term competence includes cognitive, functional, personal and ethical competence (Commission of the European communities 2005). Instead of the term competences, we propose the use of capabilities (a synonymous term that is used throughout the paper). This term encompasses various elements (Lipičnik 1998): knowledge, experience, skills (knowledge gained with training), abilities, motivation and personality characteristics.

The demands for constant learning are reflected in the widely used term "learning society", which is defined as a society in which individuals actively learn in order to gain capabilities (OECD 2001). In the last decade, the OECD countries have experienced a high rate of additional schooling and skills acquisition among employees, to ensure employability (Lesourne 2000). This demonstrates the growing need for knowledge, or broadly competences within companies and a rising trend in the formal education process of the population. Higher levels of completed education increase the probability of continuing education for these people and diminish the probability of long-term unemployment (OECD 2001). 


\subsection{Enrolement in graduate programmes in management}

Changes force managers who lead modern enterprises to engage in a constant learning process underlining the need for a continuous updating and renewal of knowledge, skills and other competences. Moreover, the learning process in management itself can even be more important than its results because gained knowledge can quickly become obsolete in business context (Lipičnik 2001; Svensson 2004; Drucker 2001).

Higher education is one of the driving forces of economic development and the main tool for transmitting collected cultural and scientific accomplishments and experience from the academic to the business sphere. Due to rapid changes in the society and business practice, continuous education of already highly educated managers demonstrates a growing area in the knowledge society (Drucker 2001). In the last two decades, higher education has become a mass pursuit in the EU as well as the US. The number of institutions with programmes in business education has soared. In the US 900 universities offered masters courses in business in 2000, in the UK the number of business schools has risen from 20 in 1980 to 120 in 2000 . Business education is also spreading around continental Europe and Asia (Pfeffer/Fong 2002).

A recent study by Graduate Management Admission Council in the US found that two-thirds of full-time MBA programmes reported an increase in applications in 2006, up from $21 \%$ the year before. According to the report, parttime programmes and executive MBA programmes experienced similar gains (News from the schools 2006). The number of students and graduates is increasing in the EU as well. In most of the OECD countries there is a clear trend of growing enrolment in higher education programmes. Many countries have already been faced with the phenomenon of "massification" (the condition also identified as "massive enrolment") (Nemetz/Cameron 2006). The percentage of the population with a university degree has risen from $22 \%$ to $41 \%$. It is anticipated that completing a tertiary level educational programme (i.e. a graduate degree) will soon become the norm (OECD 1998/2001). The value of qualification tends to diminish as it loses its exclusiveness. These days when the degrees are so commonplace, the value of the degree itself diminishes in the eyes of the employer (Yielder/Codling 2004).

In order to harmonize the qualifications gained at different universities around Europe and to increase mobility the Bologna declaration was signed by representatives of 29 countries. Each country will in the years to come reform its own higher education system so as to adopt comparable degrees, ECTS-credit system, introduce new programmes and improve their quality. Within the management programmes, students will be able to shape their own curricula based on their wants and companies' needs. This will give them freedom to develop the competitive advantages needed on the labour market. Ministers of education and training in EU countries went further in their aim to understand 
the qualifications gained in the formal process of education. They already outlined the main features of a European qualifications framework (EQF), predominantly so that the competences gained in particular programmes, either undergraduate or graduate would be more transparent and known to employers. The core element would be a set of common reference points related to learning outcomes at 8 levels.

The National Programme of Higher Education in Slovenia stresses the importance of education in order to achieve high growth and successful development of the country (Zgaga 1998). The natural consequence of perceived higher enrolment in graduate programmes thus should be increased employment and employability of people with such educational characteristics. Almost a half of all students enrolled on a yearly basis pursue studies in either management, social sciences or law (Statistical yearbooks 2002-2004). However, the question is whether companies acknowledge the role of knowledge in their overall success. All this considered it is not clear whether the demand for people with a master's degree on the Slovenian labour market is compatible with the existing supply, which will probably rise even further. The question arising is whether the growing supply of highly educated workers means they will find appropriate work. To gain deeper insight, it is necessary to examine the factors that motivate people to pursue graduate studies and determine whether employers want employees to continue with their education. If this is the case, one could conclude that enterprises need highly educated people so that knowledge can be successfully transferred from the academic to the business sphere and that a master's degree represents an opportunity in the employment and promotion process. Particularly people with a master's degree in management are suitable for managerial positions.

Another issue that demands further investigation is the percentage of students that are not employed at the time of their studies and will therefore start looking for their first job after finishing their graduate studies. Relevant information in this area makes it possible to assess whether there is a demand for new highly educated employees at all. It would be a serious problem if enterprises were reluctant to hire new employees that have chosen graduate studies immediately after receiving an undergraduate degree. This would show a negative attitude of enterprises towards the national goal of reaching a higher educational level in a minimum time and then start searching for their first employment. This information would also provide an idea about the relationship between knowledge and experience, and which of these two are seen as a priority by enterprises.

\subsection{Other characteristics of management education}

Education is a formal, planned long-term process of developing individual capabilities which consequently enable individuals to integrate into a particular 
society and working environment (Huč/Jereb 2001). The majority of business schools have a mission of educating on one side and creating knowledge by means of research. Students at business schools build their personalities and acquire knowledge that will be useful when applying for jobs. Furthermore, as a part of higher education graduate studies stimulate a broader perspective and critical thinking, offer students research-based work as well as a wide variety of capabilities. The fast pace of changes in the world calls for universities that are able to prepare business students for global conditions that are hard to predict. Economic competition stresses the requirements of managers to adapt to new circumstances and the shifting needs of companies.

By receiving a degree through formal education, an individual logically lacks the experience and skills that are required for a specific job. One acquires the functional knowledge and skills needed within the company itself. Globalization requires education that develops abilities to acquire, monitor, adapt and use knowledge. Furthermore, formal management education should strive to assist students in developing independent thinking, exercising appropriate judgement, stimulating cooperation among people and creating new situations. The ultimate aim of education is thus not transmitting knowledge, but teaching people how to learn, solve problems and incorporate acquired knowledge into new situations. (Lipičnik 2001/2002).

Universities historically underwent the process of change from being largely institutions of higher education to also assuming social functions in both research and teaching (Etzkowitz/Leydesdorff 1997). The three main roles of the educational process include teaching people how to learn, helping students build interpersonal relations and raising awareness of the problems engendered by changes in society that compound the complexity of decision-making (Whitaker 1995).

Management education is currently characterized by two trends. First, the number and variety of masters and doctoral programmes is rising on a yearly basis. In the knowledge society formal education namely serves as an entry requirement for career development. MBA programmes are expanding even faster than other academic masters programmes. Second, informal management education is receiving attention as well, which aims at acquiring skills needed in management. Universities help develop problem-solving and analytical skills, bolster self-confidence and facilitate the development of social capital (Kotter 1995). Despite the fact, that over the years there have been constant critiques of the emphasis business schools place on the acquisition of knowledge rather than development of skills and other competences, a degree in management is still crucial when applying for a position in a company. Business schools are said to fail in imparting useful skills, in preparing leaders, instilling norms of ethical behaviour, etc. (Bennis/O'Toole 2005). It seems there is a constant struggle in business education between "the demands for concentration on the needs of 
functional specialization and the demands for focus on the skills needed by the general manager to address organizational needs" (Miles 1985: 67). Leavitt in this regard suggests focusing more on education for leadership, determination, sense of duty and imagination (Leavitt 1989).

As far as the educational attainment of top managers is concerned, it can be said, that the level of education in the last decades is growing. A survey by Harvard Business School shows the situation in the US. In the 1930-2000 period the share of top managers with an MBA has risen to $50 \%$, with the highest growth detected in between 1980-2000. The percentage of managers with master's degree has been steadily rising as well. The sample shows that in the last decade there were no managers with less than college degree (Corporate leadership 2003). A survey of 6,000 MBA alumni shows that the likelihood of MBAs becoming top managers in 20 years since receiving the degree is actually more than one out of three (Steele/Ward 1974). According to Baruch and Peiperl, a graduate degree is increasingly seen as a prerequisite for senior positions (Simpson 2006). It can be speculated that the situation in the EU countries is similar. There are no available data on the educational needs of top managers in Slovenia. As it stems from the empirical results, the majority of managers in Slovenia have an undergraduate degree. The situation is slightly different than in the US or the EU.

According to the results of the research conducted at the London Business School (Tyson 2005), three global capabilities are crucial if one is to make timely decisions and achieve the desired results. First, knowledge is the starting point of a manager's career and thereby the fundamental criterion. The second element includes skills that one gains by applying the knowledge in daily activities. Finally, one needs to demonstrate appropriate attributes and behaviours in order to be able to lead people. These characteristics are in part inherited and in part acquired at later stages in career.

In the light of all critiques that business schools have been facing, particularly as regards the curriculum which tends to be academically oriented, Hogan and Warrenfeltz (2003) suggest four crucial capabilities for modern managers: intrapersonal, interpersonal, leadership and business capabilities. Intrapersonal capabilities refer to knowing oneself. Interpersonal capabilities examine one's relation with other people. Leadership capabilities involve identifying, recruiting talent and persuading people. Finally, business capabilities involve the typical managerial tools of planning, developing strategy, etc. Authors argue that traditional courses can help managers gain and improve their business capabilities, but managers are more likely to make mistakes involving the other three sets of capabilities, which are less easily addressed in a classroom.

Pfeffer and Fong (2002) compare the few studies which measure the effect of a graduate degree (MBA) on the future performance, career achievements and salary. Some show positive effects whereas other show no effect. However, the 
majority of the studies examine the graduates' current situation and do not take into account the employer's view. There is little evidence that mastery of the knowledge acquired in business schools enhances people's careers, or that even attaining the MBA credential itself has much effect on graduates' salaries or career attainment (Pfeffer/Fong 2002:80). Doubts about the value of graduate courses to managers and enterprises were expressed by different researchers (Clark et al. 2006) in terms of lack of effectiveness and skills at work. Even though the studies concerning graduate education in general as well as in business are scarce, the vast majority of them concentrate on MBA courses and not other graduate courses in management education. Shipper (1999) did however make multiple comparisons of managerial skills of recent and past MBA graduates and other graduates. In general, the comparisons failed to find that MBAs have a significant advantage in managerial skills.

\section{Methodological background}

\subsection{Main problem and research hypothesis}

The aim of the research is to determine the role of management education and important similarities, perhaps even differences, in the perception of the role of graduate education. The decision to research the role of graduate education in Slovenian enterprises is based on the following reasons. Highly educated people tend to be the driving force of excellent company performance. Consequently, the perceived trend of increasingly greater enrolment in graduate programmes leads us to hypothesize that knowledge is needed in enterprises. Graduate education and its role in this sense has not been thoroughly studied. Despite the phenomenon of knowledge society there has been little evaluation of the impact business schools have on graduate's career or the profession of management (Pfeffer/Fong 2002). Empirical studies are scarce and no studies focusing on the expectations of graduate education have been carried out in Slovenia. Assessing expectations of two populations has not yet been a focus of a study, therefore this is primarily an exploratory study. Fragmented opinions stated by students prior to the study led to conclusion that graduate knowledge in the field of management may not receive sufficient support in enterprises. Specifically, students believe that when looking for a job formal education at this level is more of a barrier than an opportunity.

Determining the kinds of expectations students and human resource (HR) managers have regarding graduate education serves as a starting point. The main area of observation lies in trying to identify what kind of role graduate education plays in a society, particularly in the business sector - namely, it is important to evaluate whether graduate education in management is useful in solving a company's problems. Despite the clearly present goal of lifelong learning, the situation in an enterprise may also prevent efficient use of employees' 
knowledge and other competences. Consequently, a question arises whether universities produce knowledge that enterprises need (how useful is this knowledge?) and whether enterprises have clear expectations about what they want? Specifically, we wish to assess whether graduate education presents an opportunity or a barrier within a company. We hypothesize that graduate education is an advantage and opportunity on the labour market, and that people with a high level of education are desired and needed in enterprises. The term "knowledge of graduates" is referred to people that have formal qualifications to occupy upper-level positions. At the same time we suppose, that it is not only factual knowledge that these people acquire during the educational process. They also gain important wider capabilities.

\subsection{Samples, collection of data and instrumentation}

In order to obtain the answer to our primary question, we carried out the study from two different perspectives, exploring two populations, connected to each another. The first survey is based on a sample of graduate students at the Faculty of Economics, University of Ljubljana, Slovenia. They are enrolled in a two year master's study (not an MBA) in the field of management. 160 first- and secondyear students participated in the study. The second sample includes large enterprises. Altogether $80 \mathrm{HR}$ managers fully completed and returned the questionnaires. This represents a response rate of $53 \%$, which we assess as good. The reasons behind choosing the populations stem from the goals of the research. In our view, the respondents are able to judge the role of graduate studies because they are either involved in the study process as students or are in the process of employing graduates as managers of human resource departments in companies. The inclusion of HR managers in the research seems appropriate because they are able to evaluate the role of graduate education at their enterprises.

The data was collected in 2003. Students of management programme filled out a specially designed questionnaire. They were asked to agree or disagree with several statements regarding the needs of graduates in the Slovenian business sector and to state their motives for studying on a scale from 1 to 6 . One limitation of the study regarding the samples is the fact that the research findings are valid only for the sample described (students in the field of management) above and cannot be generalized without preliminary research.

To explore the employability of highly educated people (i.e. the occupation of management positions in enterprises), another aspect needs to be considered. Therefore, the second sample comprises HR managers of large Slovenian enterprises. Similar to the first, the second questionnaire is designed to measure the role of managerial knowledge and other capabilities (gained within graduate programmes) as seen by enterprises. The survey was Internet-based. Respondents were asked to state the view of a particular company and its top 
management regarding the human potential. However, whether respondents stated their own opinion in some instances could not be verified. HR managers stated the enterprise's view on the need to employ people with a master's degree, the general perception of people with such a profile, the assessment of the knowledge obtained and key criteria in the process of selection. Likert scales were used whereby the measurement scale varied from 1 (not important at all or strong disagreement) to 6 (very important or strong agreement).

\section{Empirical findings and interpretation}

\subsection{Students' and enterprises' basic characteristics}

The demographic analysis shows that students that are also full-time employees are between 29 and 38 years old, have been employed for 3 to 5 years, and were at the time of study enrolled in their second year of master's studies (i.e. management programme). This suggests that so far there have not been many graduates that have decided to continue their studies at the graduate level immediately after receiving an undergraduate degree. 53\% of students received their undergraduate degree at the Faculty of Economics in Ljubljana and the remaining $46 \%$ at other faculties.

The 80 enterprises included in the research altogether employ approximately 45,000 people altogether, which accounts for 7\% of Slovenia's workforce (UMAR 2002). $73 \%$ of the respondents are women, mostly HR managers. More than half of them have an undergraduate and only $4 \%$ of them a graduate degree. $30 \%$ of the companies employ between 200 and 500 people and $16 \%$ fewer than 100.

\subsection{Enterprises' need to employ people with graduate degree}

At 37 enterprises (46\%) no people with a graduate degree are employed, and at the remaining 43 enterprises one or more holders of master's degrees are employed at the time of the survey. Therefore, descriptive statistics in this section are based only on the sample of 43 enterprises. Table 1 shows the structure of employees with graduate degree. As these are large enterprises, the figures presented show a rather surprising situation. In almost half of the enterprises employees, including those in management positions (i.e. different levels of management), do not have a graduate degree. Only 14 of the 80 enterprises surveyed employ between 5 and 10 persons with graduate degree. At more than half of the enterprises the rate of employees with graduate degree does not exceed 1\%. At twelve companies this rate is between $1 \%$ and $4 \%$, and at two companies it surpasses $10 \%$. Altogether 593 employees with graduate degree are employed at 43 enterprises. Employees with master's degrees largely work in the research and development department $(42 \%)$ or as managers of various departments (39\%). Chairman and members of the board (top 
management) in the majority of surveyed enterprises hold a graduate degree (i.e. $64 \%$ ). The educational attainment of a staggering $32 \%$ of top managers is lower than university degree. Only two top managers hold a graduate degree. The employment of holders of master's degree in the two years preceding the research is even lower. Only 22\% (18) enterprises employed 37 holders of master's degrees altogether. The majority of these employed one individual with a master's degree.

Table 1. Number of persons with graduate-level educations employed in companies in Slovenia in 2003

\begin{tabular}{|c|c|c|}
\hline $\begin{array}{l}\text { Number of persons with } \\
\text { graduate-level educations }\end{array}$ & Frequency & Percentage \\
\hline 1 & 13 & 16.3 \\
\hline $2-4$ & 12 & 15.0 \\
\hline $5-10$ & 14 & 17.5 \\
\hline $11-20$ & 2 & 2.5 \\
\hline 21 or more & 2 & 2.5 \\
\hline Total & 80 & 100.0 \\
\hline
\end{tabular}

Source: questionnaire analysis

In interpreting the statistics, it is crucial to hypothesize the reasons underlying the employment of people with graduate degree. Perhaps enterprises feel weak in a particular area and express the need to hire these people in order to receive more knowledge and abilities. It is therefore important that students know the needs of enterprises so that they can choose their curriculum accordingly. By enrolling in the revised $3+2$ programme ( 3 years of undergraduate and 2 years of graduate studies), students have a variety of subjects to choose from and thereby assure the use of their knowledge at a particular company.

HR managers believe that knowledge is a value in Slovenia and that Slovenian enterprises need employees with graduate degree (on a scale from 1 to 6 , where $1=$ strong disagreement and $6=$ strong agreement, their average choice is 4.7) and they state that holders of master's degrees have enough knowledge. Furthermore, managers perceive that the educational structure of a company directly impacts the success and competitiveness of the company (mean $=4.8$ ). HR managers and students are unanimous that Slovenia and enterprises lack employees with a graduate education. Therefore it is important that enrolment in graduate studies increases. What needs to be further stimulated is the transmission of knowledge from the academic to the business sphere. All the above statements speak in favour of knowledge gained at graduate studies. Nevertheless, research reveals that the average company would not employ another holder of a master's degree at the time of data collection. Another difference appears in assessing the potential use of graduates' knowledge. Almost half of the managers state that they do not need highly educated people at their enterprises. They do have some reservations (mean $=3.7$ ) about 
successfully applying their graduate capabilities in everyday business situations. However, their general view of this application of knowledge in Slovenia (with other enterprises in mind) is stronger (mean $=4.3$ ). When they assess the usefulness of the knowledge of holders of master's degrees in general, the estimate was higher. This stems from the situation observed in companies and managers' general opinions that graduate studies are good. However, considering data from Table 1, there is a wide gap between this stated opinion and the actual employment of people with graduate degree.

Next assessment concerns the intensity of needs for hiring graduates in Slovenia. Almost half of the HR managers respond that they do not need highly educated people, and $20 \%$ say that such needs exist but they have not done anything so far to satisfy them. Only a few enterprises plan to employ graduates in the years to come (mostly through further education of those already employed and not through external recruitment). The need to employ those with graduate degree is also reflected in enterprises' willingness to at least partly finance studies for their employees. Our study reveals that only $35 \%$ of enterprises stimulate employees to study by financing graduate studies.

It can be concluded that statistical data above show a rather contradictory situation. On the one hand, managers argue that knowledge is important to assure competitiveness, but on the other hand they do not hire candidates with graduate degrees. The reasons for such a situation are a matter of speculation. Perhaps enterprises do not know what sorts of knowledge they need, or they do not know how and where to use the knowledge that those with graduate degree have. If the latter turns out to be true, then Slovenian enterprises are in an inferior position compared to their European competition.

Enterprises that do not employ highly educated people state several reasons for not doing so. Among these are high employment costs and compensation packages, as well as unclear recruitment policy for employing highly educated people. HR managers say that, rather than formal education and knowledge, they are searching for experience in a future employee.

\subsection{Is graduate education perceived as an opportunity on the labour market?}

The attitude towards graduate education is another issue in need of addressing with regard to implementation of gained competences within the business sphere. With a rather provocative question we want to prove our initial hypothesis of the importance of knowledge. Respondents were asked to decide whether a graduate degree represents an advantage or disadvantage when an individual is looking for employment at managerial levels.

In the first case, we study the opinions of students and HR managers. The null hypothesis assumes no differences in means between the two groups. A chi- 
square test procedure is used. Analysis shows that the calculated chi value exceeds the critical tabled value and the null hypothesis can be rejected $(\chi=$ 24.09, $\alpha=.000)$. We conclude that HR managers have a different perception of graduate education than do students. $80 \%$ of enterprises perceive a graduate degree as an opportunity, yet a staggering $20 \%$ perceive it as an obstacle. The result of the students' view is extremely surprising. Altogether, $53 \%$ of students believe that a graduate degree presents an obstacle in labour market. The inherent reasons for this answer were not detected. This attitude may stem from personal experience. Perhaps respondents felt they were discriminated against in their past experiences. The foundation for such standpoint could also be a negative co-workers' attitude towards employees with graduate degree. On the labour market higher education can be an obstacle and therefore not only an advantage.

In the second case, we compare two groups of enterprises: those that do not need employees with a graduate degree (22) and enterprises that need them (31). It is necessary to evaluate how the two groups perceive graduate education: as an opportunity or an obstacle. In the alternative hypothesis we assume statistically significant mean differences. The applied chi-square test procedure shows no significant differences between the groups $(\chi=1.68, \alpha=.194)$. The null hypothesis cannot be rejected. Namely, the majority of enterprises perceive a graduate degree as an opportunity, notwithstanding whether they need graduates or not.

\subsection{Motives for pursuit of graduate studies}

Self-development, which includes formal education, is the essence of work in a knowledge economy (Brown/Hesketh 2004). Students' decision to pursue graduate studies is founded on particular reasons. They perceive education as a psychological competitive advantage in comparison with either co-workers or candidates for employment. However, although they believe in this competitive advantage, they cannot be certain. On the other hand, firms have particular expectations about the educational structure as well. They believe in the competitive advantage in the form of graduate education.

In this part of the paper we wish to examine the motives that lead people to pursue graduate studies at the Faculty of Economics in Ljubljana. Students and HR managers evaluated the importance of several motives. Both groups were surveyed in order to assess the statistically significant differences between them. The null hypothesis assumes no differences in means between the two groups. The alternative hypothesis assumes that statistically significant differences in means do exist. Table 2 presents motives for graduate studies as seen by enterprises and students. 
Table 2. Motives for graduate studies as seen by students and HR managers

\begin{tabular}{|l|c|c|c|c|c|c|}
\hline Motive for study & \multicolumn{2}{|l|}{$\begin{array}{l}\text { Importance of a } \\
\text { specific motive } \\
\text { as seen by } \\
\text { students }\end{array}$} & \multicolumn{2}{l|}{\begin{tabular}{l}
\multicolumn{2}{l|}{$\begin{array}{l}\text { Importance of a } \\
\text { specific motive as seen }\end{array}$} \\
by managers \\
and \\
significance value
\end{tabular}} \\
\hline & M & SD & M & SD & $T$-test & SIG. \\
\hline $\begin{array}{l}\text { I did not receive } \\
\text { employment with a } \\
\text { graduate degree }\end{array}$ & 1.68 & 1.37 & 3.28 & 1.53 & -7.85 & .000 \\
\hline $\begin{array}{l}\text { I did not want to be } \\
\text { employed yet }\end{array}$ & 1.57 & 1.28 & 3.61 & 1.32 & -11.48 & .000 \\
\hline $\begin{array}{l}\text { I wanted more } \\
\text { knowledge }\end{array}$ & 5.33 & 0.95 & 4.90 & 0.98 & 3.21 & .002 \\
\hline $\begin{array}{l}\text { My employer wanted } \\
\text { me to study }\end{array}$ & 1.44 & 1.06 & 3.31 & 1.13 & -12.33 & .000 \\
\hline I wanted higher pay & 3.39 & 1.70 & 4.11 & 1.26 & -3.68 & .000 \\
\hline I enjoy education & 4.31 & 1.31 & 4.26 & 1.03 & 0.29 & .751 \\
\hline $\begin{array}{l}\text { I only wanted a } \\
\text { master's degree and } \\
\text { the title that goes } \\
\text { with it }\end{array}$ & 2.57 & 1.51 & 3.44 & 1.37 & -4.31 & .000 \\
\hline $\begin{array}{l}\text { I wanted an enhanced } \\
\text { reputation in society }\end{array}$ & 2.59 & 1.48 & 4.30 & 1.24 & -8.85 & .000 \\
\hline $\begin{array}{l}\text { With a master's } \\
\text { degree I will get a job } \\
\text { easier }\end{array}$ & 2.98 & 1.64 & 4.25 & 1.12 & -7.04 & .000 \\
\hline $\begin{array}{l}\text { My friends have } \\
\text { decided to study and } \\
\text { so did I }\end{array}$ & 1.96 & 1.41 & 2.96 & 1.22 & -3.22 & .001 \\
\hline I want to be promoted & 4.11 & 1.65 & 4.70 & 1.13 & -5.39 & .000 \\
\hline
\end{tabular}

$\mathrm{M}=$ mean, $\mathrm{SD}=$ standard deviation

Scale: $1=$ unimportant motive, $6=$ very important motive

Source: questionnaire analysis

The questionnaire analysis shows significant differences in answers in all motives except one - namely, "Eagerness to learn". Students' answers show three prevailing motives: "Desire for more knowledge", "Eagerness to learn" and "Desire for promotion". Students distinctly state that receiving knowledge is the most important factor. They know they will receive more knowledge, and more knowledge is an opportunity to obtain employment, which agrees with primary hypothesis. In the case of enterprises, the answers do not vary as much. HR managers view "Desire for more knowledge", "Desire for promotion" and "Enhanced reputation in society" as three most important motives. Because the factor of receiving more knowledge has been seen as important, we can assume that students and enterprises realize that graduate studies provide the necessary knowledge. If this were not the case, students would probably not have decided to pursue their studies because they are not only time-consuming but also expensive. When deciding to pursue graduate studies, the opinion of the 
employing company is not extremely important. Contrary to the results of the survey, managers state that people with a graduate education in Slovenia tend find employment more easily. In contrast to this opinion, $45 \%$ of enterprises do not need those with graduate degree. Therefore they believe this reason is among the more important ones.

To compare the views mentioned above with the general view, we asked students what, in their opinion, motivates people in Slovenia to pursue graduate studies (whereby their own motive is excluded). Comparison of the average answers shows relatively great differences. According to the students, the prevailing motive for Slovenian students is "Higher compensation" and "Desire for promotion", whereas "Desire for knowledge and education" is given less importance. Students obviously believe that more education leads to a better position in society.

Motives for enrolment are closely connected with the benefits that graduate studies bring. Data show the crucial benefit to be "More knowledge" gained after finishing undergraduate studies. A developed "Ability for broad thinking and research-oriented work" is another benefit. This is similar to prevailing motives for studies. At the same time, more knowledge and its depth in a specific field is the most commonly stated reason for which enterprises would employ people with graduate degree in the first place.

\subsection{Characteristics employers look for in future employees}

Next assessment refers to the personal characteristics and qualifications enterprises search for in the recruitment process. We specifically want to assess whether enterprises prefer candidates with "Knowledge" (i.e. formally obtained education) or "Work experience" (i.e. the specific form of knowledge gained in particular work situations). Managers were asked to evaluate the importance of the various criteria a job candidate is evaluated upon. Students were given the same instructions. Their opinions should give an insight into their perception of the competences enterprises seek. Data obtained from the two samples enabled us to compare differences in perceptions between the two groups - that is, employers on the one hand, and employees on the other. If education were the primary competence enterprises looked for, this would be a clear signal that future employees should gain as much knowledge as possible prior to applying for a job. Table 3 presents the opinions of various employment criteria. The mean values of the importance of criteria are presented, as well as the $t$-test and significance values. 
Table 3. The importance of different employment criteria as seen by students and HR managers

\begin{tabular}{|l|c|c|c|c|c|c|}
\hline $\begin{array}{l}\text { Employment } \\
\text { criteria }\end{array}$ & $\begin{array}{l}\text { Importance of a } \\
\text { specific criterion } \\
\text { as seen by } \\
\text { students }\end{array}$ & \multicolumn{2}{l|}{$\begin{array}{l}\text { Importance of a } \\
\text { specific criterion as } \\
\text { seen by HR } \\
\text { managers }\end{array}$} & \multicolumn{2}{l|}{$\begin{array}{l}\text { T-test and } \\
\text { Significance value }\end{array}$} \\
\hline & $\mathrm{M}$ & $\mathrm{SD}$ & $\mathrm{M}$ & $\mathrm{SD}$ & $\mathrm{T}$-test & SIG. \\
\hline Ambition & 4.41 & 1.09 & 4.46 & 0.87 & -1.804 & .073 \\
\hline Formal education & 4.64 & 0.82 & 5.07 & 0.79 & -3.74 & .000 \\
\hline Motivation for work & 5.06 & 0.92 & 5.47 & 0.62 & 3.58 & .000 \\
\hline Desire for promotion & 3.98 & 1.13 & 4.57 & 0.98 & -3.91 & .000 \\
\hline Obedience & 4.03 & 1.30 & 3.63 & 1.27 & 2.18 & .030 \\
\hline Work experience & 5.03 & 0.93 & 5.00 & 0.92 & 0.19 & .846 \\
\hline $\begin{array}{l}\text { Preparedness for } \\
\text { education }\end{array}$ & 4.41 & 1.14 & 4.97 & 0.97 & -3.97 & .000 \\
\hline $\begin{array}{l}\text { Capabilities for team } \\
\text { work }\end{array}$ & 4.83 & 1.06 & 5.36 & 0.78 & -4.28 & .000 \\
\hline References & 4.26 & 1.24 & 3.83 & 1.32 & 2.42 & .016 \\
\hline Self-initiative & 4.96 & 1.00 & 5.34 & 0.72 & -3.31 & .001 \\
\hline $\begin{array}{l}\text { Broad thinking and } \\
\text { research-based work }\end{array}$ & 4.70 & 1.21 & 4.95 & 1.06 & -1.60 & .111 \\
\hline
\end{tabular}

$\mathrm{M}=$ mean, $\mathrm{SD}=$ standard deviation

Scale: 1 = unimportant criterion, 6 = very important criterion

Source: questionnaire analysis

From the managers' viewpoint, the three most important criteria are "Motivation for work", "Capabilities for teamwork" and "Self-initiative". "Formal education" and "Work experience" are given less consideration, occupying only the fourth and fifth positions. Students' scores on the same factors are lower. In their opinion, the first three positions are occupied by "Motivation for work", "Work experience" and "Self-initiative", whereas "Formal education" is in sixth place. The noted statistically significant differences in opinions stated by managers and students can result in misleading decisions. Obviously, students seem to believe that formal education is not an important criterion. In their view, work experience is far more important. Managers were asked to choose the more important factor between "Formal education" and "Work experience". The results show that experience is more important for $60 \%$ of managers. They also state that it is the role of universities to give students practical experience and that experience above all is what their enterprise needs. However, due to the variety of jobs today, one cannot expect a university to provide specific knowledge for a particular job (as is stems from theoretical part).

\section{Conclusions}

This paper explores the expectations and role of graduate education in enterprises across Slovenia as well as the employability of people with such a profile. The reason for the investigation of this issue lies in the perceived trend 
of massive enrolment in graduate programmes in management and consequently a constantly growing level of basic education. It is believed that capabilities received through formal education are of great importance for individuals when looking for a job, for enterprises and for the national economy as a whole, as it raises its competitiveness in comparison with other countries. We hypothesized that a graduate degree, which represents additional capabilities gained after an undergraduate degree, represents an opportunity on the labour market.

Results show that Slovenian enterprises and students do not see knowledge as a crucial variable in the model of economic success. There is no unanimous answer to the primary question, i.e. what is the expectation of graduate education in the field of management in Slovenian enterprises and whether graduate knowledge and skills are needed at all. Graduate education can be seen not only as an opportunity but also as a barrier.

The research shows that managers and students have different expectations about graduate education (and capabilities) and their role in Slovenian enterprises. A half of students see a graduate degree as a barrier in the process of looking for employment in Slovenia, notwithstanding the fact that they perceive graduate knowledge to be useful to enterprises. Therefore it can be deduced that more education on the labour market is not only an advantage or an opportunity. This situation, as it proceeds from our research, is alarming and calls for further consideration. Namely, thinking about knowledge of any kind as of being a barrier could create a barrier in people's minds, which could consequently lead to diminishing the desire to learn.

HR managers believe that graduate knowledge is needed in companies and a graduate degree is perceived as an opportunity. They need highly educated employees and therefore express at least a theoretical need to take on highly educated candidates. However, it has to be stressed that practice does not support this view. Almost half of the enterprises responding do not seek candidates with graduate degrees and would not employ one in the near future. Taking into account various answers, it can be concluded that enterprises express inconsistent and even contradictory views. On the one hand, they state that there is a great shortage and need for graduates, and on the other, they are reluctant to employ them.

There is a great need for additional research in this field in order to monitor whether the current trend in Slovenia is changing. Further investigation is needed into relating educational structure and the overall performance of a company. This could explain how much success could be attributed to the knowledge of highly educated employees. The usefulness of capabilities obtained at faculties requires detailed exploration and the connection between the needs of companies and the structure of the graduate programmes offered needs to be reinforced. One of the steps in this direction is the preparation of 
programmes in accordance with the Bologna Declaration, whereby students will be able to adapt their curriculum to the needs of a company.

\section{References}

Bennis, W./O'Toole, J. (2005): How business schools lost their way. in: Harvard Business Review, 5, 96-106.

Bologna Declaration on Education (June 1999): http:// europa.eu.int/comm/education/ policies/educ/bologna/bologna.pdf.

Brown P./Hesketh A. (2004): The mismanagement of talent: Employability and jobs in the knowledge economy. Oxford, Oxford University Press.

Commission of the European communities (2005): Commission staff working document.

Towards a European qualifications framework for lifelong learning. http://ec.europa.eu/ education/policies/2010/doc/consultation_eqf_en.pdf.

Delors, J. (1996): Learning - Hidden treasure - Report of the International Commission on education for the 21st century, prepared for UNESCO. Ljubljana: Ministry of Education, Science and Sport.

Drucker, P. (1993): Post-capitalist society. New York, Harper Business.

Eliasson, G. (2000): Making intangibles visible: The value, the efficiency and the economic consequences of knowledge, in: Buigues P./Jacquemin A./Marchipont J. (eds.): Competitiveness and the value of intangible assets. Cheltenham, UK, Edward Elgar Publishing Limited, 42-72.

Etzkowitz, H./Leydesdorff, L. (1997): Introduction: Universities in the global knowledge economy, in: Etzkowitz, H./Leydesdorff, L. (eds.): Universities and the global knowledge economy, New York, Pinter, 1-5.

Garsten, C./Jacobsson, K. (2004): Learning to be employable: An introduction, in: Garsten, C./Jacobsson, K. (eds).: Learning to be employable: New agendas on work, responsibility and learning in a globalizing world, Hampshire, UK: Palgrave Macmillan, 1-23.

Huč, B./Jereb, J. (2001): Vpliv izobraževanja na produktivnost in poslovne rezultate podjetja (The impact of education on productivity and business results of a firm), in: Organizacija, 34, 1, 5-15.

Hogan, R./Warrenfeltz, R. (2003): Educating the modern manager. in: Academy of management learning \& education, 2, 1, 74-84.

Kotter, J.P. (1995): The new rules: How to succeed in today's post-corporate world. New York, The Free Press.

Leavitt, H.J. (1989): Educating our MBAs: On teaching what we haven't taught. in: California Management Review. Spring, 38-50.

Lesourne, J. (2000): Education and information society, in: Buigues P./Jacquemin A./Marchipont J. (eds).: Competitiveness and the value of intangible assets. Cheltenham, UK, Edward Elgar Publishing Limited, 309-316.

Lipičnik, B. (1998): Ravnanje z ljudmi pri delu: Human resource management, Ljubljana: Gospodarski vestnik. 
Lipičnik, B. (2001a): Učenje hitrejše od izobraževanja (Knowledge is faster than learning), Organizacija, 34, 338-340.

Lipičnik, B. (2001b): Intervju: Naučeno danes - jutri zastarelo (Interview: Learned today obsolete tomorrow), Gospodarski vestnik, 36, 48.

Lipičnik, B. (2002): Knowledge and decision-making - Do we want what we need, Informing Science + IT Education Conference, University College Cork, Ireland, http://ecommerce.lebow.drexel.edu/eli/2002Proceedings/toc.htm [Accessed 15 Jan. 2005].

Miles, R.E. (1985): The future of business education. California Management Review, 3, 6373.

Nacionalni program visokega šolstva/National programme of higher education in Slovenia, http://www.mszs.si/slo/solstvo/terciarno/pdf/npvs.pdf [Accessed 15 Dec. 2004].

Nemetz, P.A./Cameron, A. (2006): Higher education out of control: regaining strategic focus in an age of diminishing resources, in: Academy of management learning \& education, $5,1,38-51$.

News from the schools (2006). Practical applications.25 th August, www.economist.com [Accessed 26 Aug. 2005]

OECD (1998): Redefining tertiary education, Paris, OECD.

OECD (2001): Education policy analysis 2001, Paris. OECD.

Pečjak, V. (1977): Poti do znanja (Paths towards knowledge), Ljubljana, Cankarjeva založba.

Pfeffer, J./Fong, C.T. (2002): The end of business schools? Less success than meets the eye. in: Academy of management learning \& education. 1, 1, 78-95.

Rajadhyaksha, U. (2003): Managerial competence: Do technical capabilities matter? in: VIKALPA, 30, 2, 45-56.

Shipper, F. (1999): A comparison of managerial skills of middle managers with MBAs with other masters' and undergraduate degrees ten years after the Porter and McKibbin report. in: Journal of managerial psychology. 14, 1-2, 150-164.

Simpson, R. (2006): Masculinity and management education: Feminizing the MBA. in: Academy of management learning \& education. 5, 2, 182-193.

Statistical Office of Republic of Slovenia (2002-2004): Statistical yearbook, Ljubljana, SORS.

Steele, J.E./Ward, L.E. (1974): MBAs: mobile, well-situated, well-paid. in: Harvard Business Review. 99-111.

Svensson, L. (2004): Lifelong learning: A clash between a production and a learning logic, in: Garsten, C./Jacobsson, K. (eds.): Learning to be employable: New agendas on work, responsibility and learning in a globalizing world, Hampshire, UK: Palgrave Macmillan, 83-107.

Tyson, L. A. (2005): On managers not MBA's, in: Academy of management learning \& education, 4, 2, 235-236.

Urad za makroekonomske analize in razvoj: Ekonomska gibanja v letu 2002 (Economic movements in 2002), http://www.sigov.si/zmar/arhiv/letno02/2td-zap.pdf. 
Whitaker, P. (1995): Managing to learn, London, Cassell.

Yielder, J./Codling, A. (2004): Management and Leadership in a contemporary university. in: Journal of higher education policy and management. 26, 3, 315-329.

Zgaga, P. (1998): Development of higher education in Slovenia, Ljubljana, Ministry of Education, Science and Sport. 